\title{
Corrigendum: Maars to calderas: end-members on a spectrum of explosive volcanic depressions
}

\author{
Danilo M. Palladino ${ }^{1}$, Greg A. Valentine ${ }^{2 *}$, Gianluca Sottili ${ }^{3}$ and Jacopo Taddeucci ${ }^{4}$ \\ ${ }^{1}$ Dipartimento di Scienze della Terra, Sapienza-Università di Rome, Rome, Italy, ${ }^{2}$ Department of Geology, University at \\ Buffalo, Buffalo, NY, USA, ${ }^{3}$ Istituto di Geologia Ambientale e Geoingegneria-CNR, Rome, Italy, ${ }^{4}$ Istituto Nazionale di Geofisica \\ e Vulcanologia, Rome, Italy
}

Keywords: maar, diatreme, caldera, phreatomagmatic, explosive eruption

\section{A corrigendum on}

\section{OPEN ACCESS}

Edited and reviewed by: Adelina Geyer,

Instituto de Ciencias de la Tierra

Jaume Almera (CSIC), Spain

*Correspondence:

Greg A. Valentine,

Department of Geology, University at

Buffalo, 411 Cooke Hall, Buffalo,

NY 14260, USA

gav4@buffalo.edu

Specialty section:

This article was submitted to

Volcanology,

a section of the journal

Frontiers in Earth Science

Received: 04 May 2017

Accepted: 11 May 2017

Published: 22 May 2017

Citation:

Palladino DM, Valentine GA, Sottili G and Taddeucci J (2017) Corrigendum:

Maars to calderas: end-members on a spectrum of explosive volcanic depressions. Front. Earth Sci. 5:42. doi: 10.3389/feart.2017.00042
Maars to calderas: end-members on a spectrum of explosive volcanic depressions by Palladino, D. M., Valentine, G. A., Sottili, G., and Taddeucci, J. (2015). Front. Earth Sci. 3:36. doi: $10.3389 /$ feart.2015.00036

Reason for Corrigendum:

In the original article (Palladino et al., 2015), there was an error in Figure 1. The vertical axis of the qualitative plot reported erroneously "ratio of juvenile to lithic materials in deposits outside of depression". The correct wording is as follows: "ratio of juvenile to total (i.e., juvenile+lithic) materials in deposits outside of depression". In fact, as it was reported correctly in the text, the amount of juvenile material (i.e., scoria or pumice) deposited ouside the different types of explosive volcanic depressions increases from zero (i.e., no juvenile, all lithic products), as is the case of hydrothermal (phreatic) explosion craters, to become largely dominant over the lithic component in the case of ash flow deposits associated with large overpressure collapse calderas. The corrected Figure 1 appears below. The authors apologize for this error and state that this does not change the scientific conclusions of the article in any way.

\section{REFERENCES}

Palladino, D. M., Valentine, G. A., Sottili, G., and Taddeucci, J. (2015). Maars to calderas: end-members on a spectrum of explosive volcanic depressions. Front. Earth Sci. 3:36. doi: 10.3389/feart.2015.00036

Conflict of Interest Statement: The authors declare that the research was conducted in the absence of any commercial or financial relationships that could be construed as a potential conflict of interest.

Copyright (c) 2017 Palladino, Valentine, Sottili and Taddeucci. This is an open-access article distributed under the terms of the Creative Commons Attribution License (CC BY). The use, distribution or reproduction in other forums is permitted, provided the original author(s) or licensor are credited and that the original publication in this journal is cited, in accordance with accepted academic practice. No use, distribution or reproduction is permitted which does not comply with these terms. 


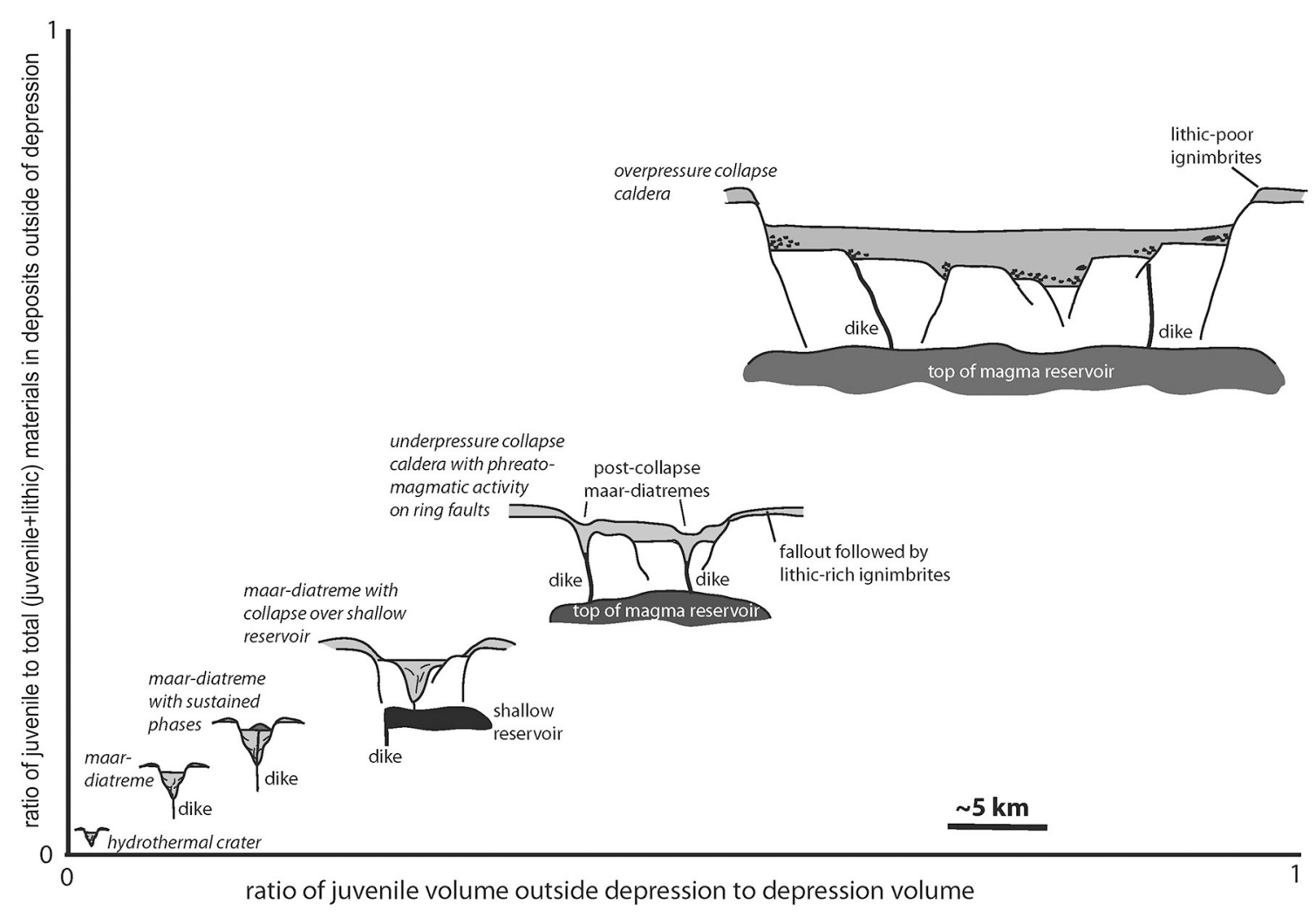

FIGURE 1 | Qualitative illustration of the spectrum of negative volcanic landforms produced by explosive eruptions, in terms of amount of juvenile material deposited outside the depression relative to lithic content and depression volume. Hydrothermal (phreatic) explosion craters are included in the diagram as extreme examples with no juvenile material, although strictly speaking they are not volcanic depressions even though they are commonly associated with volcanoes. Cartoon of maar-diatreme with sustained phases shows late-stage scoria cone in crater; although sustained, magmatic volatile-driven phases may also occur before and during phreatomagmatic activity. Cartoons, which are drawn approximately to scale, are intended to show the depressions just after formation, and thus do not show post-eruption sediments or caldera resurgent features. 